\title{
Satisfaction with Body Shape in College Students Comparisons by Gender
}

\author{
Judith M. Rodriguez-Villalobos, Veronica Benavides*, Juan C. Barron, Gerardo J. Arredondo \\ Faculty of Physical Culture Sciences, Autonomous University of Chihuahua, Chihuahua, México
}

\section{Email address:}

vbenavides@uach.mx (V. Benavides)

\section{To cite this article:}

Judith M. Rodriguez-Villalobos, Veronica Benavides, Juan C. Barron Y. Gerardo J. Arredondo. Satisfaction with Body Shape in College Students Comparisons by Gender. Psychology and Behavioral Sciences. Vol. 4, No. 6, 2015, pp. 204-207. doi: 10.11648/j.pbs.20150406.12

\begin{abstract}
The purpose of the present study was to compare the scores on body shape (current, ideal and social) and body size dissatisfaction between men and women university mexican students. A total sample of 1488 participants, 735 women and 753 men, aged 18-26 years participated in this study. A quantitative approach with a descriptive and transversal survey design was used. All the participants completed the Contour Drawing Rating Scale. The results of the one-way multivariate analysis of variance, followed by the one-way univariate analyses of variance, showed that compared with the men, the women expressed a greater discrepancy between ideal and actual body shape and had higher score of social body shape and lower score of ideal body shape. However, in the current body shape statistically significant differences were not found. Because of the differences between men and women in their perception of body image found, these findings suggest that in order to design any intervention for improving the perceived body image of the students, the variable gender should be taken into account.
\end{abstract}

Keywords: Body Image, Gender Differences, Body Size Dissatisfaction, Figure Rating Scale

\section{Introduction}

In recent years, modern societies have given excessive value to body image, many of which have created an entire subculture based on the perception and importance of the ideal body image [1].

The ideal to look thin and the concerns about the weight come from a cultural ideal that even though today is considered esthetic, is just fashion and is not necessarily healthy, neither accessible and can have negative consequences, generating anxiety, as a big concern about weight and the figure, which can be expressed as body dissatisfaction, appreciated as the extent to which people value or despise their bodies and/or in the distortion of the body image, which is the imprecision in determining the body size [2].

The adolescence and the youth period are especially vulnerable stages to experience body image problems, since they are moments in the life cycle characterized by physiological, emotional, and cognitive changes that contributes to the increase of concerns about physical appearance [3, 4]. In addition, at these stages, the desire to lose weight or stay slim is one of the most significant risk factors for eating disorders [5].
The body shape and aesthetic standards that currently govern the Western world can affect the psychological development of both men and women, but women, preteens and teens, are the ones who have a greater tendency to suffer from conflicts in the development of body image, linked to the development of problems in eating behaviors [6, 7]. This is because the standards of "beauty and thinness" are especially rigid for them [8].

Raich [9] comments that in a society that glorifies beauty, youth and health, is not surprising that the concern for physical appearance increases. In fact, millions are spent each year to improve physical appearance. But the exaggerated concern can be highly disturbing and even incapacitating for many people.

In this sense, it is particularly relevant to investigate, if belonging to a particular gender, produce or not physical and/or cognitive benefits to help reduce the concerns for physical appearance when the perception of body shape improves.

This study attempts to determine the differences and similarities between men and women Mexican university students, regarding the perception of their current body shape, ideal, social and body size dissatisfaction; considering that in recent years the body shape has taken a huge boom in modern societies, many of which have created an entire 
subculture based on the perception and importance of the ideal body shape [1].

Consequently this research aims, as an applied research, provide information that translates into a higher quality educational practice in the context of attention to diversity; contributing to pedagogical knowledge that clarifies the factors that make a model of integral human development; under the premise that educational efforts must focus on increasing feelings of self-worth and competence of students, strengthening self-esteem and self-concept, which in turn will promote the motivation for achievement, interpersonal relationships and overall the particularly way to cope against various tasks and challenges they encounter.

\section{Method}

\subsection{Participants and Design}

1488 subjects participated in the study, 735 women and 753 men all students of the degrees offered at the Faculty of Physical Culture (FCCF) of the Autonomous University of Chihuahua. The age of the subjects ranged between 18 and 26 years, with a mean of 20.46 and a standard deviation of 1.83 years.

The sample was obtained by a convenience sample, trying to cover the representation of the different semesters of both degrees.

Regarding the design of the study, a quantitative approach with a descriptive and transversal survey design was used [10]. The independent variable was gender (women and men) and the dependent variables were the scores on body shape (current, ideal and social) and body size dissatisfaction (ideal minus current body shape).

\subsection{Instrument}

Scale for the estimation of body shape, adapted and computerized for Gastélum and Blanco [11], of the original version "Contour Drawing Rating Scale" (CDRS) of M. A. Thompson and Gray [12]. The CDRS consists of seven drawings of a female figure (for female participants) (Figure 1) or a male figure (for male participants) (Figure 2). Each drawing increases in size from extremely thin (1) to very obese (9). Participants are asked to rate their current, ideal and social body shape. The discrepancy between the ideal and current size scores is an index of body size dissatisfaction.

\subsection{Procedure}

Students of the degrees offered at the Faculty of Physical Culture (FCCF) of the Autonomous University of Chihuahua were invited to participate.

Those who agreed to participate signed the consent letter. Then, the instrument explained above was applied using a personal computer (administrator module of the instrument of the scales of typical execution), in a session of about 15 minutes in the computer labs of the FCCF.

At the beginning of each session students were given a brief introduction on the importance of the study and how to access the instrument; they were asked the utmost sincerity and they were guaranteed the confidentiality of the data obtained. Instructions on how to respond were in the first screens; before the first instrument item. At the end of the session they were thanked for their participation.

Once the instrument was applied, data was collected by the results generator module of scales editor, version 2.0 [13].

\subsection{Data Analysis}

Descriptive statistics (means and standard deviations) for all the variables were calculated. Subsequently, after verifying that the data met the assumptions of parametric statistical analyses, a one-way multivariate analysis of variance (MANOVA), followed by the one-way univariate analysis of variance (ANOVA), were used to examine the differences between the women and men on the reported body shape (current, ideal and social) and index of body size dissatisfaction scores. Moreover, the effect size was estimated using the eta-squared $\left(\eta^{2}\right)$. All statistical analyses were performed using the SPSS version 20.0 for Windows (IBM ${ }^{\circledR}$ SPSS $®$ Statistics 20). The statistical significance level was set at $p<.05$.

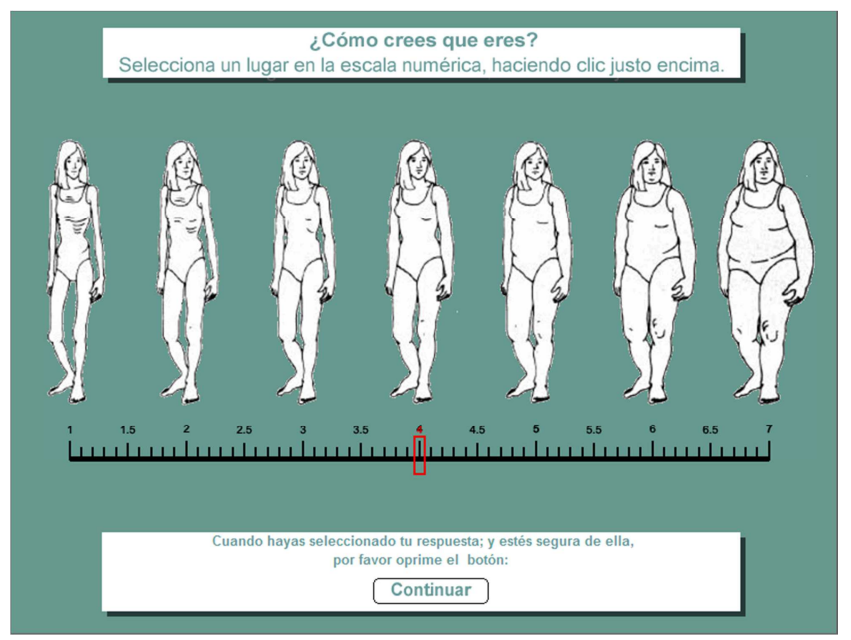

Figure 1. Sample answer to the questionnaire items. Women.

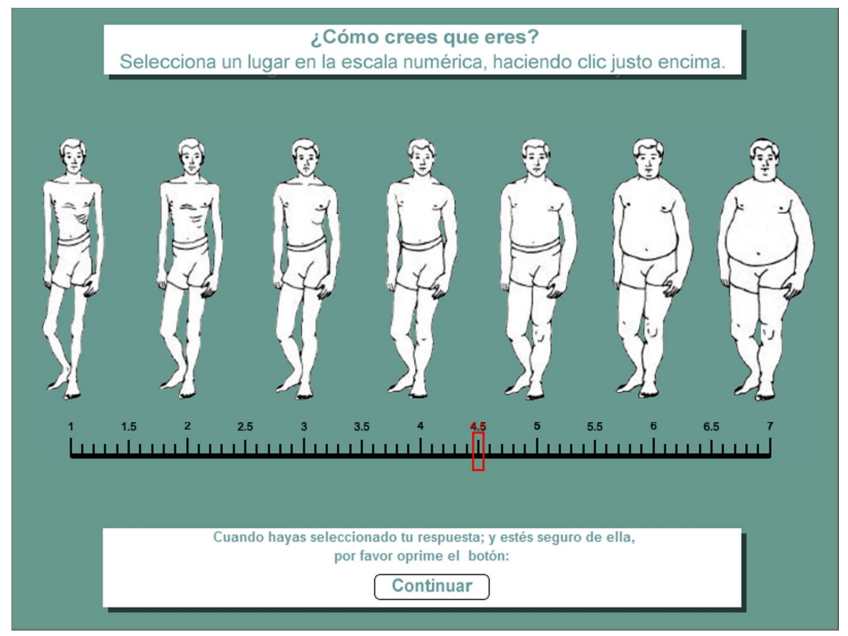

Figure 2. Sample answer to the questionnaire items. Men. 


\section{Results}

Table 1 shows the mean values and standard deviations of the variables of body shape, as well as the results of the MANOVA and the follow-up univariate ANOVAs. The MANOVA results indicated overall statistical significant differences between genders on the body shape scores (Wilks' $\lambda=.906 ; \mathrm{p}<.001 ; \eta 2=.094)$. Subsequently, the follow-up ANOVAs showed that compared with the men, the women expressed a greater discrepancy between ideal and actual body shape $(\mathrm{F}=29.407 ; \mathrm{p}<.001)$ and lower score of ideal body shape $(\mathrm{F}=124.109 ; \mathrm{p}<.001)$. However, in the current body and social body shape statistically significant differences were not found $(\mathrm{p}>.05)$.

Table 1. Results of MANOVA for the gender differences on the four variables of body shape

\begin{tabular}{llllll}
\hline & $\begin{array}{l}\text { Women } \\
(\boldsymbol{n}=\mathbf{7 3 5})\end{array}$ & $\begin{array}{l}\text { Men } \\
(\boldsymbol{n}=\mathbf{7 5 3})\end{array}$ & $\boldsymbol{F}$ & $\boldsymbol{p}$ & $\boldsymbol{\eta}^{2}$ \\
\hline $\begin{array}{l}\text { Current body } \\
\text { shape }\end{array}$ & $4.12(0.87)$ & $4.09(0.76)$ & 0.380 & .538 & .000 \\
$\begin{array}{l}\text { Ideal body } \\
\text { shape }\end{array}$ & $3.74(0.52)$ & $4.01(0.76)$ & 124.109 & $<.001$ & .077 \\
$\begin{array}{l}\text { Social body } \\
\text { shape }\end{array}$ & $4.17(4.08)$ & $4.08(1.02)$ & 2.463 & .117 & .002 \\
$\begin{array}{l}\text { Body size } \\
\text { dissatisfaction }\end{array}$ & $0.65(0.67)$ & $0.47(0.55)$ & 29.407 & $<.001$ & .019 \\
\multicolumn{5}{l}{ Note. Descriptive values are reported as mean (standard deviation). } \\
\hline
\end{tabular}

\section{Discussion and Conclusions}

The results show that, although there were no significant differences found between men and women in terms of their perception of their current and social body shape, women are those who show greater body size dissatisfaction; as well as choosing thinner models for their ideal figure, which is consistent with that is reported in other studies where it is stated that women, compared with men, of the same age and educational level, often want to be thinner or lose weight, regardless of if it is necessary [14-17]; and are more dissatisfied with their body size $[16,18]$

The results also suggest that young women may be more susceptible to sociocultural pressure that promotes unrealistic ideal of beauty; transmitted by the media, family and peers as proposed by [19-21].

\section{Conclusions}

The differences found between men and women regarding the perception of their body shape suggest that when designing any intervention that aims to improve it, it will be necessary to take into account the gender variable; however, it is necessary to develop more research on this topic because the issue goes beyond the scope of this research. The importance of more research on the subject in our country is also emphasized.

\section{Limitations of Study}

At least two limitations are present in this work. The first is that participants are only mexican university students, which threatens the possibility of generalizing these results. Expand the sample (for example adding young adults who are not students) is a work area for the future. The second limitation comes from the measuring instrument itself, which is based on self-inform and therefore may contain biases that result from social desirability.

\section{Acknowledgements}

This study is part of a project funded by the Secretaría de Educación Pública-Subsecretaría de Educación Superior-Dirección General de Educación Superior Universitaria de México [Mexican Ministry of Education-Department of Higher Education-General Directorate of the University Education] (OF-13-6894).

\section{References}

[1] S. Banfield, M.P. McCabe, An evaluation of the construct of body image, Adolescence, Vol. 37, pp. 373-393, 2002.

[2] A. Anuel, A. Bracho, N. Brito, J.E. Rondón, D. Sulbarán, Autoaceptación y mecanismos cognitivos sobre la imagen corporal, Psicothema, Vol. 24, pp. 390-395, 2012.

[3] C.J. Inglés, J.A. Piqueras, J.M. García-Fernández, L.J. García-López, B. Delgado, C. Ruiz-Esteban, Diferencias de género y edad en respuestas cognitivas, psicofisiológicas y motoras de ansiedad social en la adolescencia, Psicothema, Vol 22, pp. 376-381, 2010.

[4] J. Santrock, Adolescencia. Psicología del desarrollo, McGraw Hill, España, 2004.

[5] N. Solano, A. Cano, Ansiedad en los trastornos alimentarios: Un estudio comparativo, Psicothema, Vol. 24, pp. 384-389, 2012.

[6] R. Francisco, M. Alarcão, I. Narciso, Avaliação de factores de risco de desenvolvimento de perturbações alimentares: Desenvolvimento e estudos de validação da versão portuguesa do mcknight risk factor survey iv, Revista Iberoamericana de Diagnóstico y Evaluación Psicológica, Vol. 32, pp. 143-170, 2011.

[7] J.K. Thompson, Introduction: Body image, eating disorders, and obesity - an emerging synthesis, in: J.K. Thompson (Ed.) Body image, eating disorders, and obesity: An integrative guide for assessment and treatment, American Psychological Association, Washington, D C, 2003, pp. 1-20.

[8] M. Calaf, M. León, C. Hilerio, J. Rodríguez, Inventario de imagen corporal para féminas adolescentes (iicfa), Revista Interamericana de psicología, Vol. 39, pp. 347-354, 2005.

[9] R.M. Raich, Una perspectiva desde la psicología de la salud de la imagen corporal, Revista Avances en Psicología Latinoamericana, Vol. 22, pp. 15-27, 2004.

[10] R. Hernández, C. Fernández, P. Baptista, Metodología de la investigación, McGraw- Hill, México, 2010. 
[11] G. Gastélum, H. Blanco, Versión informatizada de la escala estimación del contorno de la figura, in: Facultad de Educación Física y Ciencias del Deporte (Ed.) X congreso internacional, facultad de educación física y ciencias del deporte, $\mathrm{UACH}$, México, 2006, pp. 285-286.

[12] M.A. Thompson, J.J. Gray, Development and validation of a new body-image assessment scale, Journal of Personality Assessment, Vol. 64, pp. 258-269, 1995.

[13] H. Blanco, M. Ornelas, J.L. Tristán, A. Cocca, D. Mayorga-Vega, J. López-Walle, J. Viciana, Editor for creating and applying computerise surveys, Procedia Social and Behavioral Sciences, Vol. 106, pp. 935-940, 2013.

[14] M.V. Acosta, J.M. Llopis, G. Gómez-Peresmitré, G. Pineda, Evaluación de la conducta alimentaria de riesgo. Estudio transcultural entre dolescentes de españa y méxico, International Journal of Psychology and Psychological Therapy, Vol. 5, pp. 223-232, 2005.

[15] G. Gómez-Peresmitré, M.V. Acosta, Valoración de la delgadez. Un estudio transcultural (méxico/españa), Psicothema, Vol. 14, pp. 221-226, 2002.

[16] F. Muñoz, M.C. Zueck, J.R. Blanco, A. Chávez, J. Jasso, Body image perception of mexican youth: A gender comparison, Education Journal, Vol. 3, pp. 261-265, 2014.
[17] M.Á. Peláez, F.J. Labrador, R.M. Raich, Prevalencia de los trastornos de la conducta alimentaria: Consideraciones metodológicas, International Journal of Psychology and Psychological Therapy, Vol. 5, pp. 135-148, 2005.

[18] C. Mercado, Aplicación del análisis de género a los trastornos de la conducta alimentaria, Revista de Salud, Vol. 4, pp. 1-14, 2008.

[19] P.A. Englera, J.H. Crowtherb, G. Daltonb, J.L. Sanftner, Predicting eating disorder group membership: An examination and extension of the sociocultural model, Behavior Therapy, Vol. 37, pp. 69-79, 2006.

[20] B. Rodriguez, H. Oudhof, N.I. Gonzalez-Arratia, C. Unikel-Santoncini, Desarrollo y validación de una escala para medir imagen corporal en mujeres jóvenes, Salud Mental, Vol. 33 , pp. 325-332, 2010.

[21] I. Jáuregui, P. Bolaños, Body image and quality of life in a spanish population, International Journal of General Medicine, Vol. 4, pp. 63-72, 2010. 